\title{
THE DANGEROUS OUTSIDER: HISTORICIZING AND INTERROGATING THE NON-NUCLEAR PROLIFERATION TREATY (NPT)
}

\author{
Efanodor-Obeten, O. H.
}

Department of Political Science and Public Administration, Edo University Iyamho, Edo State, Nigeria.

*Phone: +2348039430181*Email: efanodor.harriet@edouniversity.edu.ng

\begin{abstract}
The Non-Nuclear Proliferation Treaty (NPT) which is one of the world's most widely adopted security conventions, which also proved to be one of the most controversial treaty. Its provisions define the core bargain between those few Nuclear weapon states and numerous NonNuclear weapon states. The paper examines the NPT and undertakes an excursus on the dangers posed to the international nuclear control effort by the Democratic People's Republic of Korea (DPRK). Using secondary sources of information, the paper examines the NPT by tracing its historical basis. This enabled the study to interrogate the NPT, in spite of its major achievements, questions and criticisms are being raised about the implementation of the NPT and its overall strength. The past years have seen a series of efforts by multilateral institutions to enforce the treaty by combining restrictive measures and proposals for long-term arrangements. These efforts have not yielded results so far. The existing Nuclear Weapon States (NWS) are not required by the treaty to give up nuclear weapons but rather to negotiate in good faith. This has questioned the credibility of the nuclear states to press others to drop their nuclear ambitions. More ominous still, is the risk of the qualitative escalation of proliferation of nations following North Korea's withdrawal and series of test. The findings of the study reveal that the potential danger posed by North Korea are in threefold; firstly, if there is war in the Korean peninsula it could use nuclear weapons against its neighbors. Secondly, North Korea could help other states build a nuclear reactor that could produce materials for nuclear weapon. And lastly, North Korea's nuclear programme could breakdown the international regime intended to stop the spread of nuclear weapons. The paper concludes that the case of North Korea has proved that arms control by example is an important adjunct to specific nonproliferation treaties and cooperative measures. Although it cannot by itself stop states or leaders determined to violate an international agreement or tacit understanding, it can enhance the moral authority of the major powers to press others to drop their nuclear ambitions.
\end{abstract}

Keywords: disarmament international politics, non-nuclear proliferation treaty, North Korea, nuclear states

LICENSE: This work by Open Journals Nigeria is licensed and published under the Creative Commons Attribution License 4.0 International License, which permits unrestricted use, distribution, and reproduction in any medium, provided this article is duly cited.

COPYRIGHT: The Author(s) completely retain the copyright of this published article.

OPEN ACCESS: The Author(s) approves that this article remains permanently online in the open access (OA) mode.

QA: This Article is published in line with "COPE (Committee on Publication Ethics) and PIE (Publication Integrity \& Ethics)". 


\section{INTRODUCTION}

The dramatic progress achieved in years, with the completion of a number of treaties by nuclear powers, was followed by unprecedented levels of co-operative measures and reciprocal monitoring at missile production and destruction sites. Yet, a host of problems related to the proliferation of nuclear weapons remains as one of the most serious threat to international community and international nuclear control efforts. The hermetic secrecy of the U.S Manhattan project gave way to the public emergence of nuclear science and information technology (Clancy and Seitz (1995). According to Etemike (2012:12) technologies produced in WWII, leading to the development of atomic weapons with a destructive force immeasurably more potent than anything previously fielded transformed international relations. The security dilemma that followed produced a more ill-defined period where thousands of nuclear weapons heightened the possibility of a nuclear war. The US denotes its first nuclear bomb in 1945, in 1949 the then Soviet Union was able to test its first atomic bomb while the UK followed in 1952, and France acquired its nuclear weapon capability in 1960, followed by China in 1964. India and Pakistan in 1974 and 1978 respectively demonstrated their nuclear capabilities but were not considered full-fledged nuclear powers until 1998. These have been joined by the Democratic People's Republic of Korea (DPRK) in 2006, Israel follows a policy of nuclear ambiguity and Iran is in hot pursuit of such weapons. A variety of others seek, or have sought, nuclear forces to discourage hostility in a period of international relations history defined, in part, by a new wave of proliferation (Etemike 2012: 12; Akpotor, 2002).

Proliferation means different concepts to different people. The five acknowledged nuclear weapon states which are the United State, Russia, China, France and United Kingdom see the problem essentially as one arising out of the spread of nuclear weapons to other states. Most other states see the problem as far more complex, although no consensus view exists. The fact that 190 countries are now party to the treaty on the nonproliferation of Nuclear weapon (NPT) signaled an indication of widespread concern. It also highlights the commitment of the five nuclear weapon states to total nuclear disarmament and reflects the expectations of the non-nuclear states that this commitment is honored (Singh 1993: 37; Kmentt,2013). The non-nuclear proliferation treaty is one of the world's most widely adopted security conventions which have proved largely effective in pursuing its goals. In spite of its major achievements, questions and criticisms are being raised about the implementation of the NPT and its overall strength. In a world becoming ever more multipolar, the prejudiced structure of the treaty (between the nuclear weapons states and the non-nuclear weapon states) is less accepted today than it was during the Cold War. Many non-nuclear states are aggravated by insufficient progress on disarmament, and they wonder about the commitment of nuclear-weapon states to ultimately eliminate their weapons. A number of non-nuclear states also witness additional discrimination in the way countries outside the NPT have developed nuclear weapons, avoided pressure to disarm and India also has since 2008, obtained access to nuclear technologies (Carrel-Billiard and Wing 2010:1).

However, it is pertinent to note that, since the inauguration of the NPT as an international security regime,

many of the challenges facing the effectiveness of the NPT have continued unabated. The British American Security Information Council (2015) cited the non-universal nature of the treaty in terms of membership as the main challenge. Nwanolue and Iwuoha (2012) opined that the most serious challenge facing the NPT today is the burning quest to develop nuclear weapons by some member countries of the United Nations in blatant violation of its provisions and warnings. For example, Iran has engaged in a clandestine nuclear weapons programme for many years now. Wade 
(2006) asserts that the unchecked nuclear weapons development in North Korea and the incipient nuclear weapons programme in Iran pose seminal challenges to the nuclear Nonproliferation Treaty. Dong-Joon and Gartzke (2007) claim that the NPT membership and regime norms have modest or marginal impact on nuclear proliferation because the United States hegemony has the potential to encourage nuclear proliferation. Levite (2002) cited the clandestine nature of nuclear weapons programs as the major challenge. While Braun, Chaim, and Chybua (2004) explained that NPT is codified with dual standards where what is accepted for some nations is illegitimate for others and as such, the dual standard weakens stricture against nuclear ambitions. In another vein, the U.S delegations to the 2010 Nuclear Non Proliferation Treaty Review Conference enumerate a host of factors; first, it cited the continued noncompliance with the NPT obligations by few NPT non weapon states with reference to the unearthing of Iraqi noncompliance following the 1990-1991 Gulf war and North Korea's years of non-compliance with its NPT safeguard obligations in 2003. While it is true that the above are key challenges to the NPT, unfortunately, the document heaped the nonobservance challenge on few non-nuclear weapon states excluding the nuclear weapon states that has not demonstrated any serious efforts towards disarmament.

More ominous still is the risk of the qualitative escalation of proliferation of nations following Iraq's example in proceeding directly to the hydrogen bomb and North Korea's withdrawal and series of test. Iran's nuclear program raises questions about the possible improvement of a military capability under cover of the NPT and in contravention of treaty obligations. However, the North Korean proliferation crises represent major challenges to the NPT. North Korea is the first, and currently the only state to have announced its withdrawal from the treaty and to have built nuclear weapons. The past years have seen a series of efforts by multilateral institutions to enforce the treaty by combining restrictive measures and proposals for long-term arrangements. These efforts have not yielded result so far. Also the outcome of the six party talk of 2005 involving China, North Korea, Japan, South Korea, Russia and the United States with a view to achieving a verifiable and peaceful denuclearization of the Korean peninsula and the maintenance of peace and stability in the region has increasingly became elusive (Nwogbaga and Nnaji, 2018). While historizing and interrogating the Non-Nuclear proliferation treaty, this paper undertakes an excursus on the dangers posed to the international nuclear control effort by North Korea as an outsider. The first session of the paper will examine the Nonproliferation treaty by tracing its historical basis. The second part of this discourse will interrogate the disarmament process while the third part form the main thrust of the discourse, in what has been understood by this paper as the dangers of the outsider.

\section{HISTORICIZING THE NON-NUCLEAR PROLIFERATION TREATY (NPT)}

The US, essentially, opened the gateway to advanced Weapon of Mass Destruction (WMD). Not for lack of trying, the Nazis and Soviets lost the initial WMD arms race to the US whose Manhattan Project created the atomic weapons which were deployed against Hiroshima and Nagasaki that helped end WWII in 1945 (Etemike, 2012:13). The Baruch plan of 1946 was the first attempt to restrict the spread of nuclear weapons. The Baruch plan drew heavily on the Acheson-Lilienthal report of 1946 which proposed disarmament and the eventual demolition of the US nuclear arsenal. However, the Baruch plan was abandoned when the then USSR tested its Nuclear weapon in 1949. The Atoms for Peace programme succeeded the Baruch Plan which was an initiative of a former US President Dwight Eisenhower 
for the peaceful use of nuclear energy. The Atom for peace gave way for the International Atomic Energy Agency (IAEA) which was established in 1957. By 1958, Ireland formerly requested the creation of a UN resolution aimed at preventing further spread of nuclear weapons. It was not until 1961 that the United Nations General Assembly passed Resolution 1655 encouraging states to reach an agreement to ban further pursuit and transfer of nuclear equipment between states (BASIC 2015). Following the Cuban missile crisis which demonstrated the serious danger posed by nuclear arms and their proliferation prompted the US and the then USSR to undertake serious diplomatic measures. Thus, by 1968, the Geneva conference on Disarmament reached an agreement of a draft of the NPT. The US, United Kingdom and the then USSR were the first to sign the treaty as it's depository states while the Nonproliferation treaty entered into force in 1970 (BASIC, 2015).

Kokoski posits that the NPT created a framework for controlling the spread of nuclear materials and expertise (Goldstein and Pevehouse, 2008:11). Indeed, the signatories pledged to avoid taking any action(s) that would add to the number of countries with nuclear weapons (Rourke and Boyer, 2008:345). The treaty invariably presupposed that while the non-nuclear weapon states party to the treaty are not to manufacture or receive nuclear weapons, or any other nuclear explosive devices, the existing nuclear weapon states (NWS) are not required by the treaty to give up nuclear weapons but rather to negotiate in good faith. For the non-nuclear weapons states (NNWS) there was no room for negotiation. Consequently, the treaty established two classes of states: The Nuclear Weapon States (NWS) and Non-Nuclear Weapon States (NNWS). The nuclear weapon states are those that had conducted nuclear tests before 01 January 1967 these are United States, United Kingdom, Russia, France and China. Countries that have not signed the treaty are India, Pakistan and Israel and in 2003, North Korea withdraws from the NPT. South Sudan is the only African non-member state without a nuclear weapon program (BASIC 2015).

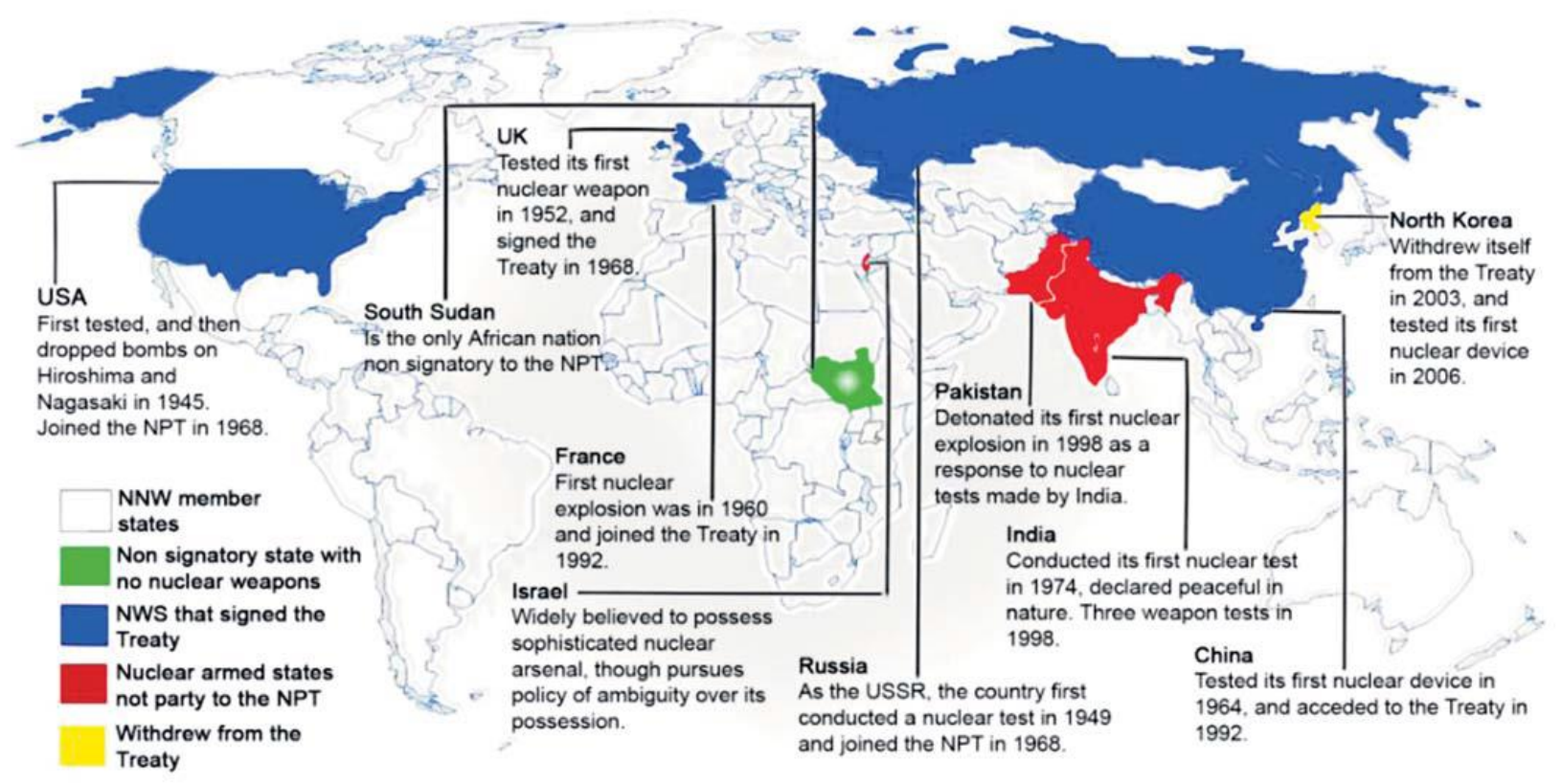

Figure 1: A summary map of the nuclear non-proliferation treaty

Source: BASIC 2015 
The NPT is broken down into three pillars; non-proliferation, disarmament and the right to nonviolent use of nuclear technology. The articles of the treaty, arguably, impose only unclear obligation that all signatories budge in the way of nuclear disarmament which was to occur under strict and effective international controls. Unfortunately, the articles do not determine a time-frame for signatories to actually conclude a disarmament treaty; they were only obliged to negotiate in good faith (Etemike, 2012:16). The NPT is interpreted as being based on three main objectives: the first is nonproliferation which is aimed at preventing further spread and transfer of nuclear weapons and technologies, or the spread of existing arsenals. The second is disarmament which is bent on furthering the goals of achieving nuclear, and broad and total disarmament. The third is on nuclear energy which recognizes the right of states to nuclear energy for nonviolent purposes and promoting international co-operation (Kimbal, 2012; BASIC 2015).

The treaty in article $\mathrm{X}$ provided for a conference to be convened 25years after its entry into force to decide whether the treaty should continue in force indefinitely, or be extended for an additional fixed period or periods. Accordingly, at the first NPT Review conference in 1995, states signatory to the treaty agreed without a veto to extend indefinitely the terms of the treaty. Thus, in every five years' states parties convene to evaluate and discuss ways in which the treaty maybe strengthened and advanced. Most of the review conferences have been clouded with disagreement between the NWS and NNWS over the fulfillment of disarmament obligations (United Nations, 2014). The nuclear powers had pledged the unequivocal desire to completely do away with their nuclear arsenals. Particularly, the 2010 and 2015 conferences raised some concerns that the NWS had not taken disarmament seriously enough, noting that progress had stalled since the end of the Cold War while the NNWS identified certain steps that should be taken. NWS should unilaterally disarm, provide more information on their nuclear capability and the implementation of disarmament agreements, reduce non-strategic nuclear weapons, take solid steps to further decrease the operational status of nuclear weapons system and involve all five nuclear powers 'as soon as appropriate' in nuclear reduction and disarmament negotiations (Johnson, 2010). The next section will interrogate the disarmament process.

\section{INTEROGATING THE DISARMAMENT PROCESS: A CASE OF HYPOCRISY IN WORLD POLITICS}

Disarmament efforts picked up speed after the dissolution of the then Soviet Union. The 1970's saw a shift towards "détente", inaugurating an era of strategic nuclear arms limitations. The Strategic Arms Limitation Treaty (SALT) and the Anti-Ballistic Missile Treaty (ABM) was negotiated. Conflicting alliances during the 1973 Arab-Israeli war draw the two super powers to the brinks of confrontation. In June 1979, the United States and the then Soviet Union reached a SALT II agreement to reduce their production of some types of nuclear weapons. In November 1981, US president Ronald Reagan presented the then Soviet Union with zero option in which all missiles would be removed. This was followed by the Regan administration unveiling in June 1982 of the Strategic Arms Reduction Treaty (START) which sought to shrink overall warhead counts and delivery vehicles to 6,000 and 1,600 respectively (Council on Foreign Relations (CFR) 2017).

On December 8, 1987 Soviet leader Mikhail Gorbachev and US president Ronald Regan signed the Intermediate-Range Nuclear Forces Treaty (INF), agreeing to eliminate grand-launched, mid-range nuclear missiles (ranging from about 300+ 3,400 miles), including the modernized US perishing II and soviet SS-20 missiles. On July 31, 1991, the Strategic Arms Reduction Treaty (START I) was signed by US president George Bush H.W. and Soviet 
leader Mikhail Gorbachev. It enters into force on December 5, 1994. The treaty was judged a success because it succeeded in limiting the United States and Russia to approximately 6,000 warheads and 1,600 delivery vehicles (Council on Foreign Relations (CFR) 2017). In May 2002, President Bush and Putin signed the Strategic offensive reduction treaty also known as the Moscow treaty. In June 2002, U.S withdrew from the Anti-Ballistic missile treaty. President George W. bush argued that the treaty limits U.S ability to develop missile defense against terrorist and rogue states. The move angered Russia, which increasingly views U.S policy post 9/11 as unilateral. Furthermore, in April 8, 2010 U.S president Barrack Obama and Russian president Dmiltry Medredev signed an arm reduction agreement in Prague, replacing the 1991 START I treaty that expired in December 2009. The new START treaty commits Washington and Moscow to reducing the proliferation of strategic offensive arms (Council on Foreign Relations (CFR) 2017).

According to Etemike (2012: 20) the new START II has not yet fulfilled its intentions. The treaty includes detailed definitions and counting rules that the US and Russia should utilise to identify the forces limited by the treaty. Both parties were expected to maintain a comprehensive database, indicating the locations, members and technological characteristics of weapons restricted by the treaty. While there were some positives sides to START II, there were also many negatives sides in terms of limits versus reduction. On the positive side, for instance, the new limit of 1550 deployed strategic warheads was 74\% lower than the 6000-warhead limit of the 1991 START Treaty, and 30\% lower than the 2200 deployed strategic warhead limit of the 2002 Moscow Treaty Warren (2011). Alternatively, START II, while limiting the number of deployable warheads, fell silent on the actual number of warheads in their arsenal. Thus, START limited the amount of deployed nuclear weapons, not the amount of weapons in total. Additionally, the treaty made no mention of how the limits would be achieved and verified. For all its successes and shortcomings START II has been polarizing. Because the US retains its nuclear deterrent and has found a way to redeploy its nuclear weapons without decommissioning them. Like Russia, the US is unwilling to disarm rendering START II moot (Etemike 2012:20).

According to Etemike (2012: 22), equipped with such old-fashioned thinking, the NWS were caught completely off-guard as the threat of nuclear terrorism thrust the nuclear clock a minute closer to Armageddon following the 11th September 2001 terrorist attacks in the US and the arrest of a man thought to have constructed a 'dirty bomb' by mixing plutonium with conventional explosives. The threat was further increased as a wave of socalled "rogue" states began to seek revisions of the distribution of power associated to possession of nuclear weapons. The only solution to such challenges, as the logic of the Cold War dictated, was to react on a tit-for-tat basis. Hence President Bush having viewed multilateral non-proliferation agreements as inherently unverifiable and overly constraining of US security strategy, simply side-stepped, ignoring the CTBT, pursing national missile defense and developing a nuclear bunker-buster weapon (Warren 2011). He explored the option of putting anti-missile weapons in space and reached a nuclear cooperation deal with India, which is not party to the NPT (Warren 2011). While Russia developed the SS20 a stealth delivery system and China increased the tempo of its nuclear programme; steps deemed to negate the spirit of disarmament.

During Obama's presidency, while publicly supporting the eradication of all nuclear weapons, emphasized that the US will not disarm unilaterally and that as long as nuclear weapons exist, it will retain a strong, safe, secure, 
and reliable nuclear deterrent (Etemike, 2012:22). According to the Federation of American scientist, as at 2017, there are around 14,935 warheads.

\section{Where the World's Nuclear Weapons are}

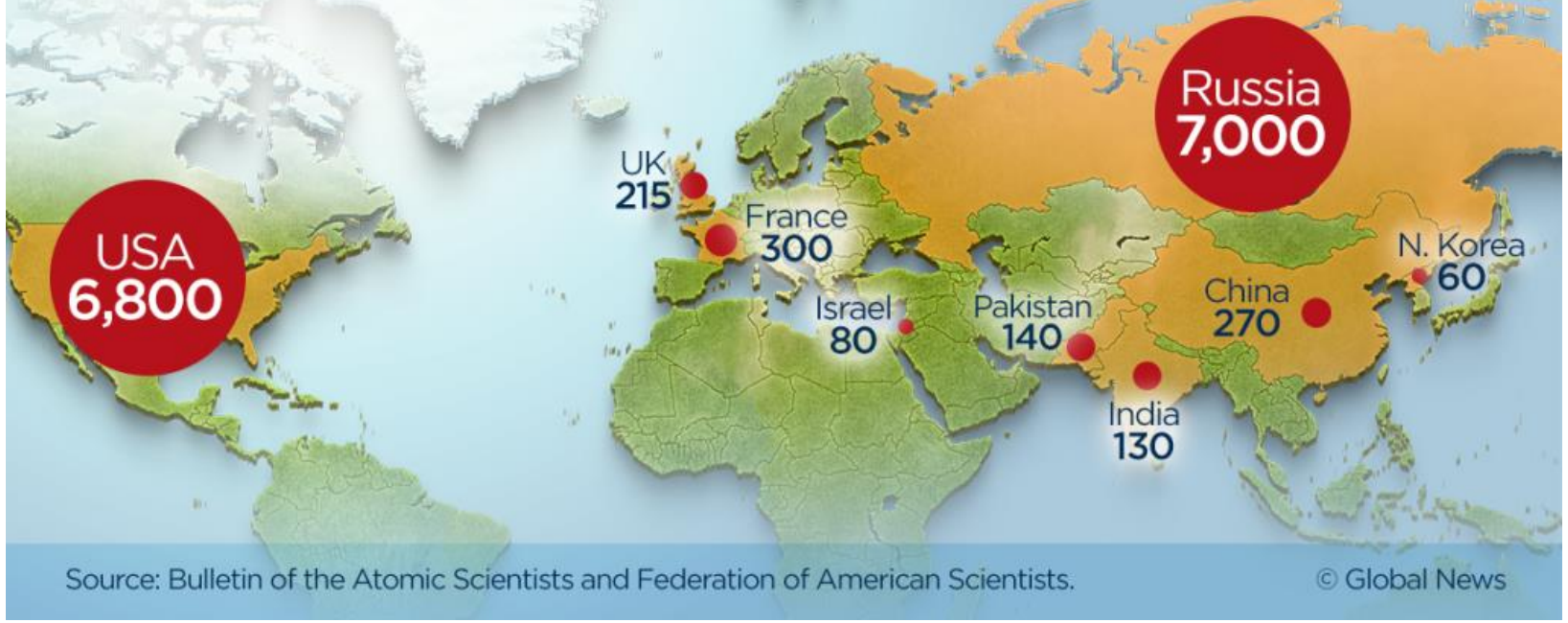

Figure 2: Map showing states with nuclear weapons and estimated number of nuclear warheads.

Source: Bulletin of the Atomic Scientists and Federation of American Scientist 2017

The number given in the map is the total estimated inventory, which counts warheads in military stock pile though retired, but still intact, awaiting dismantlement. Of these 14,930 nuclear weapons, 9,400 are in the military stockpiles and others are awaiting dismantlement. Around 1,800 U.S, Russia, British and French warheads are on high alert, ready for use on short notice. Approximately, 93 percent of all nuclear warheads are owned by Russia and the U.S with each having an estimated 4,000-4,500 warheads in their military stock piles (Dangerfield, 2017). Below is the US nuclear weapons inventory 2017. 


\section{US Nuclear Weapons Inventory 2017}

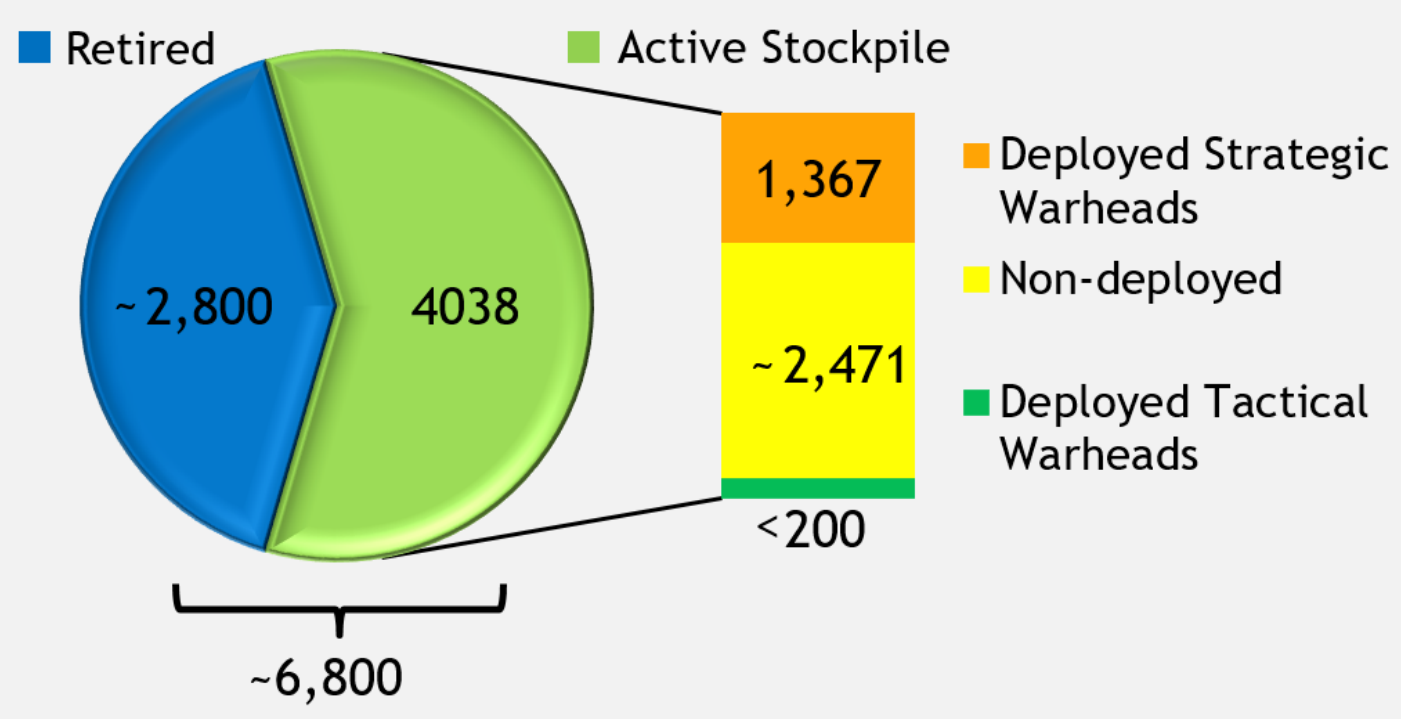

Source: U.S. Department of State, Federation of American Scientists

Figure 3: US nuclear weapons inventory 2017

Source: Center for Arms Control and Proliferation (2017)

According to the Center for Arms Control and Non-Proliferation (2017) there is no doubt that the number of nuclear weapons in the world has declined significantly, down from a peak of approximately 70,300 in 1986 to an estimated 14,900 in 2017. However, it is significant to note that, although the number of nuclear weapons is decreasing, spending is on the rise in 2017. The diagram below show how nuclear weapons spending is one the increase while non-proliferation spending is decreasing. 


\section{Nuclear weapons spending goes up:}

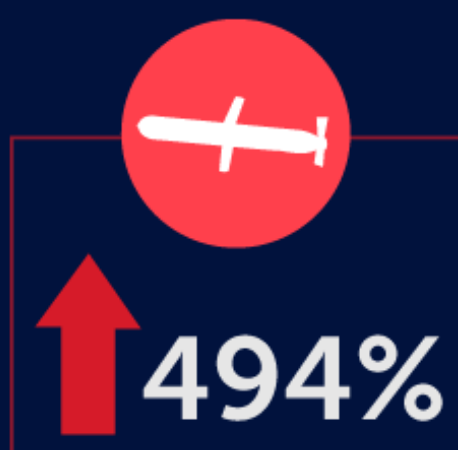

New Nuclear Cruise Missile
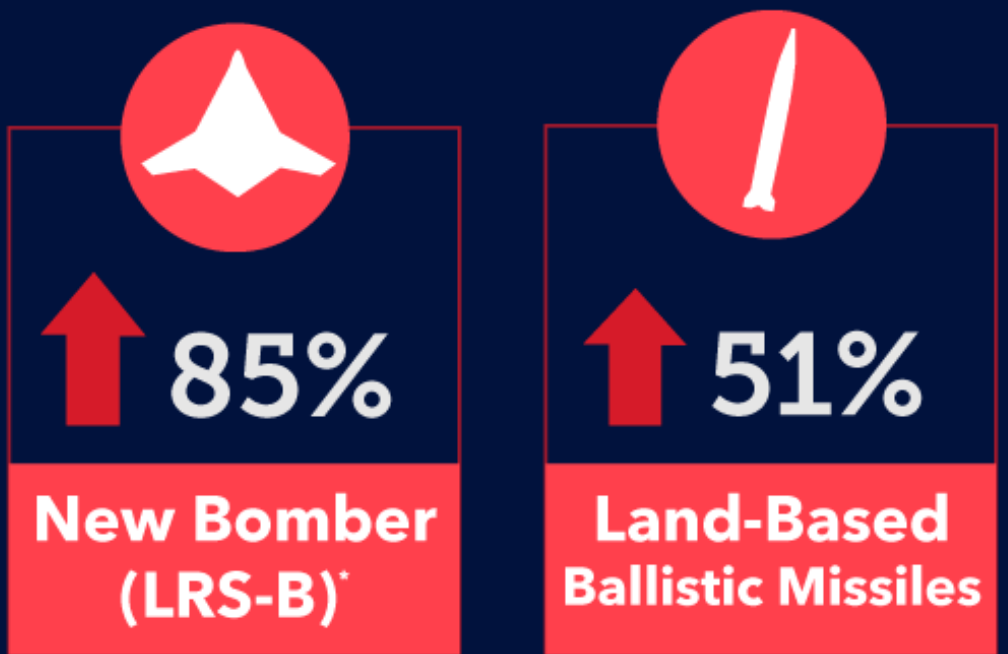

\section{Non-proliferation spending goes down:}

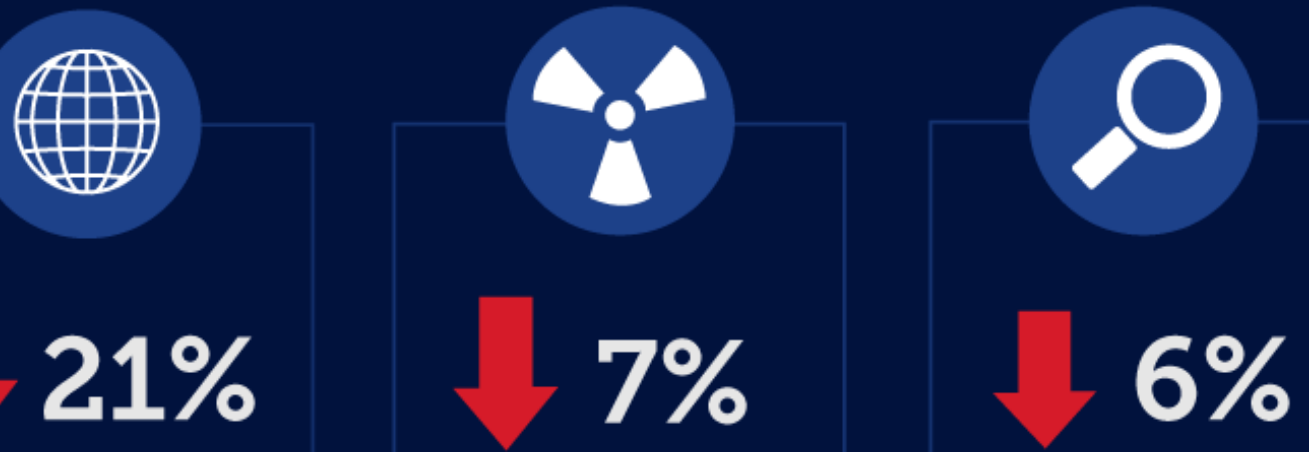

Figure 4: Nuclear weapon spending 2017

Source: Center for Arms Control and Non-proliferation (2017)

The Center for Arms Control and Proliferation illustrate that in February 2017, U.S President Donald Trump reiterated that the US will build up the US nuclear arsenal to ensure it is at the top. The U.S is believed to be lacking behind in its atomic weapon capacity; therefore, the US government plans to spend about $\$ 350$ billion on modernizing and maintaining its nuclear forces and facilities.

This prompted Taylor to conclude that as long as nations possessing nuclear weapons continue to behave as though they feel more secured with them than without them, more non-nuclear states can be expected to join the nuclear club. Firstly, between 1975 and 1996, the US authorized transfers of nuclear parts to the UK under a National 
Security Decision Memoranda. It is also true that some of the fissile materials for the UK Trident Warhead were purchased from the US Department of Defence and property services. This was certainly against the spirit of the NPT and reveals that nuclear states can freely interact while insisting on a ban for others underlining that the difference between NWS and NNWS is absolute, sending the message to other states that acquiring nuclear weapons increases national power and bargaining positions. Okonkwo, (2009:15) suggests that without an effective and collective action towards disarmament, the NPT's continued efficacy and viability will be called into question.

\section{NORTH KOREA: THE DANGEROUS OUTSIDER}

Although the Treaty is nearly universal in its membership, four states with nuclear weapons capabilities remain outside: India, Pakistan, Israel, and North Korea. These countries have no legal obligation to work towards nuclear disarmament or to refrain from assisting NNWS on any nuclear weapons programs (Bunn, 2003). Israel, India, and Pakistan have been 'threshold' countries in terms of the international non-proliferation regime. India, Israel and Pakistan are publicly opposed to the NPT and have consistently attacked the treaty since its inception, labeling it, as a treaty in favor of the existing nuclear powers. In contemporary times, of these four states, North Korea nuclear development remains a major challenge for the nuclear non-proliferation regime (Carrel-Billiard and Wing (2010). The Democratic People's Republic of Korea (DPRK) signed the NPT in 1985, but in 2003 announced that it would no longer be bound by the treaty. North Korea first tested a nuclear weapon in 2006.

The DPRK took initial steps towards the development of a civilian nuclear program in the 1950s. DPRK signed several agreements to cooperate on training with the Soviet Union. In 1959, the Soviets agreed to supply the DPRK with a research reactor, and to assist in the development of a nuclear-research center. By the early 1960s, the DPRK had received the research reactor and construction of the Yongbyon Nuclear Research Complex. The research reactor is believed to have come on line in 1967. In the 1970s, the DPRK strengthened its indigenous capabilities; this included upgrading the research reactor and constructing a university based "experimental nuclear facility." (CarrelBilliard and Wing (2010).

According to Carrel-Billiard and Wing (2010), North Koreans started work on the experimental reactor at Yongbyon, which was indigenously designed. It would use natural uranium, mined in North Korea. By the beginning of the 1980s, the DPRK therefore had within its borders all the necessary elements for an indigenous program: expertise, their own supplies of natural uranium; and experience in building and operating nuclear facilities. During the 1980's they began to build a $50 \mathrm{MW}(\mathrm{e})$ and a $200 \mathrm{MW}(\mathrm{e})$ reactor. The DPRK also started the construction of a "radiochemical laboratory," essentially a reprocessing facility. And they requested two additional reactors from the Soviet Union (Carrel-Billiard and Wing (2010). Two points are important here: the DPRK's nuclear program is longstanding, beginning only a few years after the founding of the country itself; and although the DPRK had external assistance in the very early days of its program, it had developed its indigenous capabilities quite early in the program's history (Carrel-Billiard and Wing (2010). Below is the list of nuclear tests since 2006. 
Table 1: List of North Korea's nuclear test since 2006

\begin{tabular}{ll}
\hline 4-5 July, 2006 & Seven ballistic missiles including its long-range missile, the Taepo Dong-2 was \\
launched from the Kittaraeyong test site. & Launched underground rocket engine at its Punggye-ri test site \\
9 October, 2006 & Launched underground rocket engine at its Punggye-ri test site \\
25 May, 2009 & Launched underground rocket engine at its Punggye-ri test site \\
12 February 2013 & Launched underground rocket engine at its Punggye-ri test site \\
$6^{\text {th }}$ January, 2016 & Launched two intermediate range Musudan missiles \\
$28^{\text {th }}$ April, 2016 & Launched another intermediate range Musudan missile. \\
$30^{\text {th }}$ May, 2016 & Launched underground rocket engine at its Punggye-ri test site \\
$9^{\text {th }}$ September, 2016 & Test launch surface intercontinental ballistic missiles \\
$1^{\text {st }}$ January, 2017 & Launched surface to surface medium range ballistic missile \\
$12^{\text {th }}$ February, 2017 & Launched four missile targeting U.S military base in Japan \\
$6^{\text {th }}$ March, 2017 & Missile was fired into sea off east coast of North Korea \\
$5^{\text {th }}$ April, 2017 & Launched unsuccessful missile test \\
$29^{\text {th }}$ April, 2017 & Test launched Hwasong-12 believed to be North Korea's longest-range missile and \\
$14^{\text {th }}$ May, 2017 & solid fuel Pukguksong-2 missile which defies UN security council's resolutions and \\
& sanctions \\
$25^{\text {th }}$ August, 2017 & Test launch three short range ballistic missile to the northeast. \\
$28^{\text {th }}$ August, 2017 & Launched Hwasong-12 missiles, which flew over 2,700km and overflew Japan. \\
\hline & Source: compiled from www.armscontrol/org/factsheet/dpkchronology \\
\hline
\end{tabular}

The main benefits that has been advanced by North Korea for nuclear weapons are; first, to guarantee the security of the state. Second, it is seen as the engine to economic development and prosperity and thirdly, gaining respect and prestige in the international arena. The potential danger posed by North Korea can be summarized as follows; firstly, the most immediate danger is that North Korea could use nuclear weapons against its neighbors, South Korea and Japan, if there is war on the peninsula. Secondly, North Korea has already help Syria build a nuclear reactor that could produce materials for nuclear weapon which was destroyed by Israel warplane in 2006. If North Korea's inventory of nuclear bombs grows, its technological base expands and its need for hard currency to help cope with international sanctions increase, Pyongyang and his successors will have larger inventory merchandise, plus the incentives to look for overseas buyers. Thirdly, North Korea's programme could breakdown the international regime intended to stop the spread of nuclear weapons. Fourthly, it could generate instability leading to a nuclear coup, nuclear civil war or bomb leaking beyond the North's borders (Suk Hi Kim and Seliger, 2011).

According to Slavin (2003), Ashton Carter, a former Defense Department official had earlier warned on the potential danger of North Korea's nuclear programme that: first, North Korea might sell or trade plutonium and nuclear technologies. Secondly, other developing nations would follow North Korea's example. Carter's 2003 warnings have become increasingly prophetic as time passes. Since 2003, North has developed more sophisticated WMDs, such as 
nuclear weapons, missiles, and others. Now the Korea country not only has sufficient bombs to deter a war, but enough to sell to other countries or even to terrorist groups. Pyongyang widely exported missiles and nuclear technologies to Syria, Libya, Pakistan, Burma, and Iran (Hecker et al, 2010).

According to Suk Hi Kim and Seliger, (2011) the Korean nuclear standoff has become a high-stakes game, which poses greater threats than those posed by Iraq and Iran. North Korea sits in the heart of northeast Asia, amid some of the world's largest and fastest growing economies, which are alarmed by the prospect of war or the collapse of an impoverished regime. What should worry the region and the world is not only the threat posed by the bomb but also the large number of nuclear plants in neighboring countries of Japan and South Korea that are vulnerable to attack if war breaks out. Most of the reactors in Japan and South Korea were built in clusters, which mean their destruction could lead to levels of contamination greater than in Chernobyl and Fukushima. There are no easy solutions to the North Korean nuclear problem. The United States and its allies have used sanctions against North Korea for the last sixty years; at times they have been useful in moving North Korea back to negotiations and slowing down its development of nuclear weapons. However, in the long run, they have hardened North Korea's resistance to international cooperation and reinforced its isolation from the international community (Kartman, Shirk, and Delury, 2009:248). The nuclear issue in general and the NPT and North Korea unsettling conflict shows empirically indefensible irrationality at the heart of the normative framework (Gebru, 2015)

\section{CONCLUSION}

The sad truth is that proliferation cannot be stopped. The nuclear non-proliferation treaty bars development by or transfer of the weapons to non-nuclear states. It has done some good, but it has not prevented additional states from acquiring the bombs. The number of warheads proliferated is on the increase. The twin objectives of non-proliferation and disarmament set out in the NPT have not been met. This makes it necessary to establish a more viable nonproliferation regime for the twenty first century. The NPT has also given nuclear weapons certain legitimacy, while at the same time tending to provide a false sense of security. States which adhere to the treaty as non-nuclear weapon states are believed to be such, although the reality may be different, as Iraq's example shows. The biggest problem with nuclear weapons may be described as one of asymmetry of capabilities. Asymmetry creates greater complexities and uncertainties in multi-polar situations where nuclear weapons of one state have implication for a number of others. Inevitably asymmetry increases with the increase in the number of nuclear weapon states, creating instability and providing a powerful incentive for proliferation.

Arms control by example is an important adjunct to specific nonproliferation treaties and co-operative measures. Although it cannot by itself stop states or leaders determined to violate an international agreement or tacit understanding, it can enhance the moral authority of the major powers. Evidence of serious intent to implement supplier retrain to pursue deeper nuclear force reductions, to destroy conventional weapons and nuclear warheads, to stop fission-able materials production, and to cease nuclear testing would bolster the case for demand reduction in the proliferation arena. It would also strengthen the hand of the major powers in making the case for taking collective action whether export controls, political and economic sanctions, or military measures against any state that violates international agreements or standards. 


\section{REFERENCES}

Akpotor, A.S. (2002). International Relations: An Introduction. Edo State: INNO Printing Press.

Braun, Chaim and Chyba (2004). Proliferation Ring: New challenges to the Nuclear Non-Proliferation Regime. International Security. 29(2):5-49

British American Security Information Council (BASIC) (2005). The Nuclear Non-Proliferation Treaty (NPT). www.basicint.org.

Carrel-Billiard, F. and Christine W. (2010) Nuclear Energy, Non-proliferation and Disarmament: Briefing Note for 2010 NPT Review Conference. New York: International Peace Institute. https://www.ipinst.org/wp-content/uploads/publications/nuclearcomplete2.pdf

Center for Arms Control and Proliferation (2017) www.armscontrolcenter.org/factsheet-u-s-nuclearwarhead

Clancy, T. and Seitz R. (1995). Five Minutes Past Midnight and Welcome to the Age of Proliferation. In Purkitt (ed) World Politics. USA: The Dushkin Publishing Group Inc.

Council on Foreign Relations (2017) US-Russia Nuclear Arms Control 1948-2010. Retrieved from www.cfr.org/timeline/us-russia-nuclear-arms-control

Dangerfield, D. (2007) There are 14,935 nuclear weapons in the world. www.globalnews.ca/new/37095/countries-nuclear-weapon.

Doon-Joon, J. and Gartzke, E. (2007) Determinants of Nuclear Weapon Proliferation. Journal of Conflict Resolution, 51(1):167-194.

Etemike, L. (2012). The Politics of Nuclear Non-proliferation. Central European Journal of International Security Studies. 3-7: 11-26

Hecker, S. (2010). Lessons Learned from the North Koran Nuclear Crises, Daedalus: 5.

Rourke, J. and Boyer, M. (2004). International Politics on the World Stage, New York: McGrew-hills, p. 268.

Gebru, A. L (2015). North Korea's Nuclear Program and the Treaty on the Non-Proliferation of Nuclear Weapon: The Controversy and its implication. African Journal of Political Science and International Studies. 9(9):349-360.

Goldstein, J. and Pevehouse, J. (2008). International Relations, New York: Pearson Longman, p. 210.

Kartman, C. Shirk, S. and Delury, J. (2009). North Korea Inside Out: The Case for Engagement, Asia Society and the University of California, October 2009, pp. 39.

Kimball, D. (2012). The NPT at a Glance. Arms Control Association, April 2012, www.armscontrol.org/factsheets/nptfact

Kmentt, A (2013). How Divergent Views on Nuclear Disarmament Threaten the NPT. Arms Control 
Association, December 2013, www.armscontrol.org/act/2013_12/How-Divergent-Views-OnNuclear-Disarmament-Threaten-the- NPT

Leviate, A.E. (2002). Never Say Never Again: Nuclear Reversal Revisited. International Security. 27(30):59-88

Menselson, J. (1995). Dismantling the arsenals: arms control and the new world agenda. In Purkitt (ed) World Politics. USA: The Dushkin Publishing Group Inc.

Nwanolue, B. O. G. and Iwuoha, V. C. (2012). The Treaty on the Non-Proliferation of Nuclear Weapons and the Challenges of Nuclear Capability Projects in Iran and North Korea. African Journal of Political Science and International Relations 6(5):104-111

Nwogbaga, D. M.E and Nnaji, F. (2018). North Korea's Defiant Quest for Nuclear Armament and the Implication for Global Quest for Nuclear Armament and the Implication for Global Peace and Security in the 21st century. A paper presented at the 31st Annual Conference of Nigerian Political Science Association (NPSA) on State, Governance and Regional Integration in Africa. March 2629th, 2018.

Okonkwo, P.U (2009). Nuclear Weapons in Middle East. Port Harcourt: Classique Press.

Johnson, R. (2010). Successful Conference: Now Words into Ac $\neg$ tion,' Sixth NPT Review Conference, 20 May 2019. Available at: www.ac $\neg$ ronym.org.uk/npt/18.html.

Singh J. (1995). The Bomb or Peace in Purkitt (ed) World Politics. USA: The Dushking Publishing Group Inc.

Slavin, B. (2003). US Fears Spread of North Korea Nukes. www.usatoday.com.

Suk Hi Kim and Seliger B. (2011) U.S Policy on a nuclear North Korea in Suk Hi Kim, Terence R. and Selinger B. (eds) The Survival of North Korea: Essay in Strategy, Economics and International Relations. North Carolina: McFarland and Co.

United Nations (2014). Final report of the Preparatory Committee for the 2015 Review Conference of the Parties to the Treaty on the Non-Proliferation of Nuclear Weapons," May 2014, United Nations, www.un.org/ga/search/view_doc.asp?symbol=NPT/CONF.2015/1

Wade, L. H. (2006). Rebels without a Cause: North Korea, Iran and the NPT. International Affairs. 82(4):723-742.

Warren, A. (2011). The Prague Vision: An Assessment of Obama's Nuclear Policy. Available at: http://law.anu.edu.au/coast/events/APSA/ papers/64.pdf 